\title{
NUME DE SĂRBĂTORI ÎNTRE SACRU ȘI PROFAN
}

\author{
DELIA ANAMARIA RĂCHIȘAN \\ Universitatea Tehnică din Cluj-Napoca, \\ Centrul Universitar Nord Baia Mare, România \\ CĂLIN TEOdOR MORARIU \\ Universitatea din Oradea, România
}

\begin{abstract}
Names of celebrations between sacred and profane
Abstract: This paper aims to highlight the impact that certain Romanian celebrations have on the mentality of people from rural and urban areas, emphasising the dichotomy which is established between the sacred and the profane in names of celebrations with a fixed date (Blagoveștenie, Alexii, Sângiorz, Sântandrei etc.) and customs with a varying date (Paparuda, Caloianul etc.) from the folk and Christian calendars. Certain aspects are underlined: on the one hand, the passage from ethnology towards linguistics is pointed out; on the other hand, it is shown that names of celebrations are directed at, sometimes correlated with names of certain saints acting as spiritual patrons. The etymological perspective, the interdisciplinary approach (from the viewpoint of linguistics, ethnology, religion, and mythology), the isotopes (avimorphous, human, superhuman and zoomorphic), the eponymous and synchronic analysis, as well as the interaction between sacred and profane reveal the complexity of Romanian celebrations.
\end{abstract}

Keywords: onomastics, sacred, profane, celebrations, customs.

\section{Introducere}

Lucrarea își propune să evidențieze în ce măsură dihotomia sacru-profan interacționează cu denumirea unor sărbători cu dată fixă și mobilă din spațiul cultural românesc. Sărbătorile devin punct de conjuncție între Calendarul Creștin și Calendarul Popular. Sesizăm contaminări, la nivelul sărbătorilor cu dată fixă, între Calendarul Creștin (Sfântul Cuvios Alexie, omul lui Dumnezeu - 17 Martie; Buna Vestire - 25 Martie; Sf. Mare Mucenic Gheorghe, purtătorul de biruință - 23 Aprilie; Sfântul Apostol Andrei, cel Întâi chemat, Ocrotitorul României - 30 Noiembrie) și Calendarul Popular (Alexii - 17 Făurar; Blagoveștenie/Ziua Cucului - 25 Mărțișor; Sângiorz - 23 Prier; Sântandrei - 30 Brumar). Obiceiurile cu dată mobilă (Paparuda, Caloianul) par a fi când sub tutela sacrului, când sub tutela profanului. Prin prisma binarității sacruprofan se au în vedere anumite aspecte: glisarea dinspre etnologie înspre lingvistică; asocierea sărbătorilor cu sacralitatea, cu anumiți sfinți, considerați a fi patronii spirituali; perspectiva etimologică, augmentată de perspectiva interdisciplinară (lingvistică, 
etnologie, religie, mitologie); izotopiile (avimorfă, umană, supraumană, zoomorfă); eponimia; analiza sincronică; toponimia, pornind de la hidronime, oiconime, microtoponime, hodonime.

\section{Binaritatea sacru-profan la nivelul sărbătorilor cu dată fixă din calendarul creștin și calendarul popular}

Sărbătorile menționate în calendarul creștin și în calendarul popular uneori se suprapun, alteori apar contaminări sau diferențe majore. Pentru o perspectivă comparativ-analitică, în cele ce urmează, analizăm sărbătorile menționate așa cum apar în calendarul creștin și în calendarul popular:

a Sfântul Cuvios Alexie, omul lui Dumnezeu - 17 Martie (calendarul creștin)

Termenul alexie înseamnă „cecitate verbală”, „incapacitatea de a citi”. Antroponimul Alexie provine din limba greacă (gr. alexein „a apăra”) și a generat o serie de antroponime: „Alexe, Alexi, Alexa, Alexoi, Alexu, Alixă, ucr. Olexa, Alexoi, Alexoniiu” (Constantinescu 1968: 7). Antroponimul este un hipocoristic al compuselor grecești cu alex-: „Alexandros, Alexarhos, Alexippos, Alexamenos” (Petrache 1998: 19). În Maramureș întâlnim antroponimul Alexâie.

Sărbătoarea creștină (re)amintește de Sfântul Cuvios Alexie, considerat a fi omul lui Dumnezeu, datorită calităților sale - bunătate, evlavie, smerenie. Conform unei legende, Alexie este fiu de împărat. Părinții îi aleg o mireasă și îl însoară. Deoarece dorea să fie mai aproape de Domnul, Alexie se retrage, pe furiș, într-o mănăstire. Când călugării vor să îl ridice în rang, Alexie refuză și părăsește lăcașul de cult. Se reîntoarce în împărăția tatălui său. Purtând haine ponosite, arătând ca un cerșetor, nimeni nu îl recunoaște. Primește o odaie.

Într-o zi au bătut din senin clopotele bisericii. Săracul decedase. Avea în mână o scrisoare. Doar împăratul a reușit să i-o ia din mâna încleștată. Citind scrisoarea respectivă a aflat adevărata identitate a decedatului - era fiu său. A fost înmormântat cu fast. Datorită bunătății, smereniei devine sfânt și an de an este cinstit pe 17 Martie $^{1}$.

\section{$a_{2}$ Alexii - 17 Făurar (calendarul popular)}

Denumirile regionale (Moș Alexe, Alexă cel cald, Ziua Șarpelui, Ziua Peștelui, Retezatul Stupilor) potențează variabilitatea denominativă, însă și rolul, caracteristicile, importanța sărbătorii, îndeletnicirile oamenilor în ziua respectivă. Pornim de la premisa că modele denominative populare, enumerate mai jos, se bazează pe o gândire empirică:

$\mathbf{a}_{2 \mathrm{i}}$ MoșAlexe (re)amintește de cultul strămoșilor; de status-ul lui Alexie, conform mentalității oamenilor trăitori în lumea satului românesc;

1 Vezi legenda în detaliu la Marian 2011: II, 126-135; pentru o analiză comparativ-analitică, vezi și Viața Sf. Cuvios Alexie, omul lui Dumnezeu, https://doxologia.ro/viata-sfant/viatasfantului-cuvios-alexie-omul-lui-dumnezeu. 
$\mathbf{a}_{2 i \mathrm{i}}$ Alexă cel cald anunță schimbarea vremii și anotimpul primăvara;

$\mathbf{a}_{2 \mathrm{iii}}$ Ziua Șarpelui face trimitere la simbolul saurian despre care se crede că iese în ziua respectivă din pământ;

a $_{\text {2iv }}$ Ziua Peștelui trebuie corelată cu Sfântul Alexie, cu sfântul făcător de minuni pe ape, cu începerea anului piscicol;

$\mathbf{a}_{2 \mathrm{v}}$ Retezatul Stupilor anunță scoaterea mierii din stup.

\section{Alexiile și legendele}

La nivelul legendelor, indiferent de variantă, remarcăm două izotopii: izotopie antropomorfă și izotopie avimorfă. Totodată, sesizăm două ipostaze: Alexiepersonaj, Alexie-sărbătoare. Spre deosebire de Sfântul Petru, care are la brâu o cheie, Alexe/Alexie are la brâu două chei: cu o cheie deschide Pământul (17 martie); cu cealaltă cheie închide Pământul (14 septembrie). Conform unei legende, Moș Alexe a primit de la Dumnezeu o ladă pe care nu a avut voie să o deschidă (izotopie antropomorfă). Nerespectând porunca divină, deschide lada, iar din ea ies insecte, reptile, rozătoare, gângănii care împânzesc Pământul. Drept pedeapsă, Moș Alexe a fost metamorfozat în cocostârc (Marian 2011: 142). Se crede că, de atunci, pentru a se hrăni și pentru a curăța pământul, simbolul avimorf (cocostârcul) prinde broaște, șerpi etc. Din pricina greșelii, curiozității omenești, Moș Alexe generează hybris [depășește măsura]. Dumnezeu îl sancționează. Status-ul de om este substituit cu status-ul avimorf. Așadar, conform actului punitiv, Moș Alexe, prin metamorfozare, își pierde statut-ul de om, devine pasăre, o făptură necuvântătoare. Conform acestei legende, Alexie-personaj este o ființă umană cu defecte și calități. În acestă legendă nu are status-ul unui sfânt.

Raportându-ne la sărbătoare, de Alexii, în toate regiunile țării noastre, în livezi, în grădini, se aprind focuri de purificare care au menirea de a de/(re)sacraliza spațiul locuit de om: „se aprindeau focuri prin grădini și livezi, se ocoleau casele și acareturile cu tămâie și cârpă arsă pentru alungarea șerpilor și insectelor” (Ghinoiu 2013: 17). Sesizăm un cumul de funcții: apotropaică, de fertilizare, de purificare.

b Buna Vestire - 25 Martie (calendarul creștin) este asemenea unui halo aflat sub oblăduirea sacrului. Când cade în postul Sfintelor Paști se face dezlegare la pește și la vin. Termenul [buna+vestire] este format după limba slavă (<sl. blagověštenije). Remarcăm izotopia religioasă: Maica Domnului este anunțată de Arhanghelul Gavril că îl va naște pe Pruncul Sfânt. Denumirea regională Zămislirea Domnului reamintește de vestea primită de Fecioara Maria. În iconografie și în pictura murală, Arhanghelul Gavril are un crin în mână, simbol al purității Maicii Domnului. Există și icoane care o înfățișează pe Maica Domnului având în mână un crin, iar în brațe ținându-l pe Pruncul Sfânt.

\section{b 2 Blagoveștenie/Ziua Cucului - 25 Mărțișor (calendarul popular)}

Denumirea Blagoveștenie (<sl. blagověštenije) conferă sărbătorii o conotație sacră - izotopie religioasă. În lumea satului, a doua zi se sărbătorește Blagoveșnicul, 
denumit și Gavril Blagoveșnicul. Denumirea regională Ziua Cucului subliniază faptul că accentul cade asupra funcției oraculare - izotopie avimorfă. Cucul, pasărea oraculară, mesager al iubirii, poate fi analizat din mai multe perspective ${ }^{2}$. Praxis-ul ritual anunţă complexitatea sărbătorii: „Se făcea foc în grădină pentru paza pomilor, să nu vină bruma"-Moldova (**Sărbători și obiceiuri. Răspunsuri la chestionarele Atlasului Etnografic Român. 2004: IV, 321); „la Blagoveștenie, copiii luau un lanț și înconjurau casa de trei ori, strigând: «Fugiți șerpi, șopârle/Că vin Blagodatele/Să vă rupă spatele» ca să nu mai fie goange" - Transilvania (***Sărbători și obiceiuri. Răspunsuri la chestionarele Atlasului Etnografic Român. 2003: III, 286); „La Blagoveștenie se punea salcie și ceva nărunzat (ceva roșu, fire de lână roșie) la poartă și la stâlpul casei” - Oltenia (*** Sărbători și obiceiuri. Răspunsuri la chestionarele Atlasului Etnografic Român. 2001: I, 270).

\section{c Sărbătoarea Sfântul Gheorghe - 23 Aprilie (calendarul creștin)}

Această sărbătoare trebuie corelată cu denumirea din limba latină Sanctus Georgius. Din forma latină avem: Sângers, Sângeorz, Sângerdz, Sângirogi, Giorzu, Jordzeanul, Giorziu, Sânzor, Gheorghe provine din limba greacă (georgós „agricultor”). Alte forme: Gheorghi, Gheorghieş, Gheorghişor, Gheorghiu etc. (Constantinescu 1963: 68). Antroponimul Gherghina apare menționat în documentele muntenești: „E posibil ca antroponimul să fie un format românesc faţă de Gheorghe (Gherghi), [...] existent și azi, ca variantă a lui Gheorghe, sau este împrumutat din bulgară” (Pătruț 2005: 32). Antroponimul Gheorghe a suferit o serie de modificări: „a pătruns prin intermediar slav, iar din a doua jumătate a secolului trecut, Gheorghe a trecut printr-un proces de latinizare după modelul lui Georgius, formă latină a numelui amintit" (Petrache 1998: 53). În iconografie, în picturile murale din interiorul bisericilor este redată lupta dintre bine și rău - Sfântul Gheorghe ucide balaurul.

\section{c Sângiorz - 23 Prier (calendarul popular)}

De Sângiorz, în viața păstorilor, avea loc un eveniment important - aprinderea focului viu. Există manifestări agrare care pot fi corelate cu Sângiorz. De exemplu, Tânjaua din Hoteni prin care se sărbătorește primul gospodar care a ieșit la arat are loc, în prezent, în Maramureș, în a doua duminică a lunii mai. În trecut avea alte denumiri: Craiul Gheo (izotopie umană); Boii Sângiorzului (izotopie zoomorfă).

\section{d, Sfântul Apostol Andrei, cel Întâi chemat, Ocrotitorul României - 30 Noiembrie (calendarul creștin)}

Sfântul Apostol Andrei ${ }^{3}$ este venerat și respectat de creștinii din diferite țări, indiferent de confesiunea religioasă (ortodocși, romano-catolici, greco-catolici): Grecia,

\footnotetext{
2 Vezi cucul abordat din mai multe perspective (cuc-sărbători; cuc-categorii folclorice; cuc-categorii estetice, artă tradițională) la Răchișan; Morariu 2017: 158-166.

3 Vezi detalii despre Apostolul Andrei la Răchișan; Morariu 2016: 24-36.
} 
Scoția, România, Rusia, Ucraina. Este ocrotitorul spiritual al României și al Scoției (drapelul Scoției are ca simbol Crucea Sfântului Andrei). Uneori, sărbătoarea creștină Sfântul Andrei este prăznuită în perioade diferite. De exemplu, rușii, ucrainenii prăznuiesc sărbătoarea pe 13 decembrie, conform calendarului iulian.

Biblia, în Evanghelia după Matei, îl prezintă ca fiind ucenicul lui Ioan Botezătorul; fratele Apostolului Petru: „Pe când umbla pe lângă Marea Galileii, a văzut doi frați, pe Simon ce se numește Petru și pe Andrei, fratele lui, care aruncau mreaja în mare, căci erau pescari. Și le-a zis: «Veniți după mine și vă voi face pescari de oameni»” (*** Biblia 1997: Matei 4-5, 18-19, 1100). Fiecare apostol a propovăduit cuvântul Domnului în diverse colțuri ale lumii: „După tradiție, lui Toma i-au căzut sorții să meargă în Parția, lui Andrei în Sciția, lui Ioan în Asia” (Eusebiu de Cezareea 1987: 99). Apostolul Andrei a fost mesagerul Domnului în diverse colțuri ale lumii: Asia Mică, Peninsula Balcanică, Sciția (zonele din nordul Mării Negre și Dobrogea), în sudul Rusiei de astăzi, Grecia.

Crucea în formă de „X” (re)amintește de martiriul Apostolului Andrei despre care se crede că a fost răstignit, la Patras, în Grecia, cu capul în jos pe o cruce în formă de „X”. Obiectele din lemn (pecetare/lăzi de zestre/mărțișorul tradițional din Maramureș/porți tradiționale din lemn/sărărițe), veșmintele tradiționale (cămăși/ii/ spăcele) care au ca motiv Crucea Sfântului Andrei (în formă de „X”) capătă o funcție „apotropaică” [de apărare]. Crucea Sfântului Andrei, având, de data aceasta, funcție utilitară, apare și pe indicatoare - cale ferată fără bariere cu o singura linie; intersecție de drumuri; semn de circulație cu oprirea interzisă. Uneori, Crucea Sfântului Andrei este supusă desacralizării. De exemplu, omul modern preferă să poarte cravată cu „nodul Sf. Andrei" [St. Andrew knot].

\section{$\mathrm{d}_{2}$ Sântandrei - 30 Brumar (calendarul popular)}

Conform Calendarului Popular se pornește de la premisa că sărbătoarea Sântandrei face parte din cele 35 de zile consacrate de daci lupului. Se crede că Apostolul Andrei, denumit și Apostolul lupilor, este Marele Lup Alb, care, conform legendelor, a propovăduit credința. Inițial a fost om, apoi a fost metamorfozat în lup, într-un simbol totemic asociat cu dacii (dáoi < „lupi”). Denumirile regionale anunță cât de fragilă este granița care se instituie între sacru și profan: Andreiu', Andreluşă, Andreiul lupilor, Apostolul lupilor, Indrei, Indreiul lupilor, Gădinețul Șchiop, Noaptea Strigoilor, Sântantrei, Sânt Indrea, Sfântu' Andreiu', Ziua Luptilor, Ziua Lupului etc. Datorită variabilității denominative sesizăm o varietate de izotopi:

$\mathbf{d}_{2 \mathbf{i}}$ izotopie religioasă: Sântantrei, Sânt Indrea, Sfântu' Andreiu' - denumiri regionale aflate sub tutela sacrului;

$\mathbf{d}_{2 \mathrm{i}}$ izotopie zoomorfă: Andreiul lupilor, Apostolul lupilor, Indreiul lupilor, Gădinețul Șchiop (gădineț, godin, godineț < „porc tânăr”; mutație funcțională; desacralizare); Ziua Luptilor, Ziua Lupului - remarcăm relația triunghiulară: Apostolul Andrei-lupi-daci;

d $_{2 \text { iii }}$ izotopie antropomorfă: Andreiu’ (gr. Andréas „bărbătesc” < andro- „bărbat”, subst. andreia „bărbăție, curaj”), Andreluşă (sufixele generează diminutive, iar 
diminutivele contribuie la formarea hipocoristicelor ${ }^{4}$ : Andreicuță, Andriță, Andrițoiu), Indrei (reprezintă o formă veche românească ${ }^{5}$ utilizată în prezent în Țara Lăpuşului). Antroponimul are o „semnificație augurală [...]. Numele a pătruns la noi înainte de venirea slavilor, fiind preluat de populația daco-romană din latina balcanizată, unde circula printre creștini” (Petrache 1998: 21).

$\mathbf{d}_{2 \mathrm{iv}}$ izotopie supraumană: Noaptea Strigoilor - un remediu contra forțelor supraumane îl constituie crucile din usturoi aninate la uși și ferestre: „strigoii se manifestau violent față de oamenii care nu își luau anumite măsuri de protecție" (Ghinoiu 2005: 244).

Uneori, interdicțiile și predicțiile potențează sacralitatea (post, rugăciune), alteori accentul cade pe desacralizare (practici magice: legarea obiectelor contondente ferăstrău, foarfecă, pieptene, „hrebdinca” [perie cu dinți de lemn sau cu dinți de fier prin care se trecea fuiorul de lână sau de cânepă, după ce a fost zdrobit cu melița]; practici magice de visare/de aducere a ursitului în cazul fetelor nemăritate etc.

Antroponimele din prezent, în funcție de spațiul cultural/de zona etnografică/de regiune, capătă o anumită influență:

- influență grecească: Andreadi, Andreopol, Androae;

- influență slavă: Andreica, Andreiciuc, Andreievici, Andruc, Andrușco, Andruț;

- influență maghiară: Andor, Andraș, Andrașoni, Andreș, Ondraș.

\section{Dihotomia sacru-profan și sinonimia, antinomia, eponimia}

Uneori, prenumele sfinților, menționați în această lucrare, în calendarul creștin și în calendarul popular generează sinonimie, antinomie, eponimie:

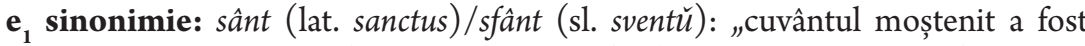
încorporat în cel împrumutat (sfânt în loc de sânt)" (Felecan N. 2011: 243); Sfântul Gheorghe, Sfântul Andrei (calendarul creștin) - Sângiorz, Sântandrei (calendarul popular);

$\mathbf{e}_{2}$ antinomie: Sântandrei (Sfântul Andrei)-Sânpetru de Iarnă (Sfântul Petru); Sântion de Primăvară (Dragobete, 24 Făurar/Februarie)-Sântion de Vară (24 Cireșar) Iunie; 29 Gustar/August) - Sântandrei și Sânpetru sunt considerați, în popor, protectori ai lupilor, nu trebuie confundați, sunt sfinți diferiți; Sântion de Primăvară este o denumire regională a sărbătorii Dragobete, se pune accent pe dragostea curată, $S f$. Ioan Botezătorul a propovăduit statornicia; Sântion de Vară este denumirea regională a sărbătorilor creștine: Nașterea Sfântului Ioan Botezătorul (24 Iunie); Tăierea Capului Sfântului Prooroc Ioan Botezătorul (29 August) - Calendarul Ortodox;

$\mathbf{e}_{3}$ eponimie: prenumele sfinților menționați este transferat asupra sărbătorii.

4 Diminutivele nu trebuie confundate cu hipocoristicele: „Diminutivele se formează, în primul rând, de la substantivele comune, pe când hipocoristicele numai de la nume de persoane" (Graur 1965: 57).

5 Există numeroase forme vechi introduse prin in- 1. Indre, - $a$; 2. Indrei, Indriü; 3. Indries, Indreș; 4. Indrul + Adrian: Andreian, - $a$; cu în- „1. Îndreiu; 2. Îndriǔu; 3. Îndreeșĭ 4. Îndrieș; 5. Îndreica" (Constantinescu 1963: 11). 
Anumite cuvinte din prezent sunt desemantizate, desacralizate. De exemplu, Undrea echivalează cu luna Decembrie (Calendarul Popular), iar substantivele andrea/undrea desemnează niște instrumente cu funcție utilitară: „acele (lungi și groase) cu care se împletesc obiecte de lână, de bumbac; ac mare pentru cusut saci, saltele" (DEX 1998: 39). Cele două cuvinte nu au legătură etimologică.

\section{Binaritatea sacru-profan. Toponimia ${ }^{6}$, pornind de la sărbătorile cu dată fixă, de la hidronime, oiconime, microtoponime, hodonime}

f. hidronime: Alexeni (județul Suceava, afluent al râului Dorna), Andra (județul Vrancea,cursdeapăceformeazărâulAlba,MunțiiVrancei);AndrașFilip (județulHarghita, curs de apă, afluent al râului Vinul); Androchiel (județul Sibiu, curs de apă, afluent al râului Hârtibaciu); Gheorghe (județul Neamț, curs de apă, afluent al râului Schitu), Sfântu Gheorghe (județul Maramureș, curs de apă, afluent al râului Băița) (https://ro.wikipedia. org/wiki/List\%C4\%83_de_cursuri_de_ap\%C4\%83_din_Rom\%C3\%A2nia_-_A.

g. oiconime: Andrăsești (Ialomița); Andreești (județul Vâlcea); Andreești (Gorj); Andreiaşu de Jos, Andreiaşu de Sus (județul Vrancea); Andrieșeni (județul Iași); Sântandrei (județul Bihor); Sfântul Andrei (Scoția); Andreeni (Harghita); Andreeni (Ucraina); Sângeorz-Băi (județul Bistrița-Năsăud), Sfântu Gheorghe (judetul Covasna) 7 .

h. microtoponime: Editura Andreiana (Sibiu); Hotel Plutitor Sf. Andrei (Tulcea); Peștera Sfântul Apostol Andrei (județul Constanța).

i. hodonime: Sf. Andrei-Iași; București; Sângeorz-Băi; Sânzieni-sector 2, București, Sf. Gheorghe-Iași; Sf. Gheorghe-Miercurea Ciuc (http://strazi.rou.ro/.

j. denumirea locașului de cult însoțită de hram: Biserica Sfântul Andrei (București); Biserica Sfântul Andrei și Buna Vestire (Caracal); Biserica Sfântul Apostol Andrei (Oradea); Mănăstirea Sf. Gheorghe (județul Timiș); Mănăstirea Buna Vestire (Sângeorz-Băi, județul Bistrița-Năsăud); Mănăstirea Buna Vestire (județul Giurgiu). Denumirea lăcaşurilor de cult din România devine punct de conjuncție între sacru şi profan. Profesorul Nicolae Felecan, în studiul Sacru și profan în denumirea mănăstirilor din România, indică modalitățile de atestare a mănăstirilor în spațiul public .

6 Potrivit etimologiei toponimelor, multe au la baza nume proprii, nu nume de sfinți.

7 Într-un oraș multicultural, precum Sfântu-Gheorghe se remarcă aspecte hodonimice negative, dat fiind faptul că multe străzi cu nume-simbol pentru români au fost substituite în anul 2010, la cererea primarului maghiar și Consiliului Local, cu nume maghiare, „,̂n concordanță cu configurația etnică a orașului” (Felecan O. 2013: 324-325).

8 Vezi și alte mănăstiri, accesând Ghidul mănăstirilor din România, site: http://ortodox.ro/ manastiri.

9 Vezi un studiu important care vizează: două sisteme de dominație (oficial și popular); particularități geografice; fapte istorice; voievozi, monahi, ctitori de lăcașuri sfinte; trăsături de limbă cu referire la lexic, fonetică, topică, ortografie, inconsecvență în respectarea tipicului, la Felecan N. 2013: 431-439. 


\section{Dihotomia sacru-profan. Obiceiurile cu dată mobilă (Caloianul; Paparuda)}

Obiceiurile agrare - Caloianul; Paparuda, practicate în vreme de secetă, după Paști, ori de câte ori este nevoie (marțea/joia/duminica), au un caracter ambivalent şi cuprind anumite secvențe: invocație, îndrumare, rugăminte, motivație. Obiceiurile menționate anterior sunt precreștine, de origine păgână, însă recuzita magică inserează și obiecte cu conotație sacră (busuioc, coji roșii de ou - Caloianul). Caloianul și Paparuda sunt obiceiuri agrare practicate de copii în beneficiul comunității și nu trebuie confundate cu jocurile de copii. Copiii au un status apare - emană inocență, puritate.

k. Caloian (alte denumiri regionale: Scaloian/Calaiman/Caluian/Iene/Ene/ $G_{h e r m a n^{10}}$ ) este denumirea obiceiului, însă și a figurii antropomorfe confecționată din lut (slava veche kalŭ „lut”)/ din cârpe. Păpuşa antropomorfă este îngropată, apoi dezgropată și aruncată în apă. Actanții devin altcineva (popă, dascăl, stegar, purtătorii sicriului).

În bulgara dialectală, regăsim forme diminutivale, gen kalojanče, kaloenčo, care au legătură cu antroponimul Caloian ${ }^{11}$.

Caloianul (re)amintește de sărbătoarea Argeilor, de cele douăzeci și patru de păpuşi antropomorfe, confecționate din paie sau din cârpe, legate de mâini și de picioare și scufundate în apă: „la idele lui Marte trebuiau aruncate în Tibru. Aceste păpuși se numeau și ele Argei, după numele capelelor în care erau depuse. Două luni mai târziu, la idele lui Maiu, aceste păpuși în chip de om, care înlocuiau desigur sacrificii omenești din vremuri îndepărtate, erau scoase din capelele lor de către fecioarele vestale și duse pe Pons sublicius" (Vulcănescu 1985: 422). Se credea că scufundarea în apă aduce ploaia.

Bulgarii îl plămădesc din lut pe Gherman (figura antropomorfă are o jumătate de metru, ochii din cărbuni; coji roșii de ou pe cap; în pântece îi înfig o broască omorâtă recent). Fetele își intră în rol, una este mama, alta este popa, alta este cioclul - îl bocesc, fac priveghiul, dau de pomană. Figura antropomorfă este îngropată sau aruncată în apă $\breve{~}^{12}$.

În spațiul cultural românesc, Caloianul reprezintă moartea și viaţa. În trecut se plămădeau două figuri din lut, una masculină - Tatăl soarelui; alta feminină - Muma ploii: „După zvârlirea pe apă a Caloianului se spunea: «A murit Tatăl soarelui și a înviat Muma ploii!»” (Vulcănescu 1985: 423).

1. Paparuda ${ }^{13}$ este un obicei agrar care cunoaște o serie de denumiri regio-

10 Gherman este un rit magic specific bulgarilor, asemănător Caloianului; în zona Banatului se serbează Ghermanul cu cinci zile înainte de Ispas; în Muntenia apare cu sensul „păpuşă de lut”; ceremonialul de vară împotriva secetei, nu are legătură cu Sf. Gherman, Patriarh al Constantinopolului între anii 715-730 (Mihăescu 2005: 62-63).

11 Unii corelează obiceiul cu numele țarului Ioniță, supranumit Caloian, alții cu numele Sf. Ioan Botezătorul, cu Sântilie. Vezi Mihăescu 2005: 40.

12 Vezi detalii la Vulcănescu 1985: 422.

13 Papa s-ar putea să provină dintr-o rădăcină indo-europeană din care derivă un termen 
nale: Babaloaga, Băbărugă, Bozul, Dodoloaie, Mămăruța, Papăruie, Paparug, Papălugă, Papalunga, Păpărudă, Peperugă, Pipiruga etc.). Indiferent de denumire este o divinitate invocată pentru a aduce ploaia: „srb. dődola «paparudă» (pl. dődole «ceata paparudelor») este un regionalism semnalat în Vojvodina, format la rândul său din refrenul muzical Oj dódo + le, care însoțește acolo obiceiul respectiv" (Mihăescu 2005: 53). Termenul paparuda este o tautologie. Romulus Vulcănescu identifică termenul generic, formele dialectale întâlnite la români și străini: paparugă (Banat), papăruie, păpărugă, papalugaia (Transilvania), papalugă (Moldova), băbărugă (Bihor), dodoloaie, dodolița (Banat, Crișana), peperuna (albanezi), peperudă, peperugă (bulgari), pepelugă (sârbi), pipieruga, perpeira (greci) ${ }^{14}$. Primul nume, papa ne duce cu gândul la penat (zeul care păzește roadele câmpului), la lar (zeu al vetrei); rudă, în slavă, înseamnă „seminție, rudenie, legătură de sânge"15. La nivelul obiceiului impresionează masca fitomorfă totală. În funcţie de regiune se folosesc frunze de bozie, de nuc etc.

Atât Caloianul, cât și Paparuda sunt obiceiuri străvechi. Sesizăm că peste mitul precreștin se suprapune cel creștin. Analizând aceste obiceiuri, inclusiv sărbătorile menționate anterior avem o perspectivă comparativ analitică.

\section{Binaritatea sacru-profan. Nume de sărbători, nume de vinuri și de soiuri de struguri}

La nivel oenologic [enologic] remarcăm denumiri de vinuri și de soiuri românești care fac trimitere la simboluri religioase, mitologice și implicit la binaritatea sacru-profan. Numele de vinuri și de soiuri de struguri românești pot fi analizate din perspectivă lingvistică și pragmatică ${ }^{16}$. Numele unui vin, indiferent dacă face trimitere la religie sau la mitologie, poate să devină un brand cultural național ${ }^{17}$. Vinurile care au ca eponim numele unor sfinți - Sfântul Andrei - crama Oprișor (http://wine-boutique.ro/vinuri/ vinuri-romanesti/sfantul-andrei); Sfântul Gheorghe - (http://www.vinmag.ro/oprisorsfantul-gheorghe-2011.html, crama Oprișor, gama Cupola Sanctis) sau denumirea unor obiceiuri - Caloian - crama Oprișor-Caloian Rozé, Fetească Neagră Caloian, Merlot Caloian (http://vinul.ro/caloian-de-oprisor.html); au la bază considerente comerciale

grec, tradus „strămoș, moș mitic”; lat. pappus „moșneag, bătrân”; rudă, termen slav de origine indo-europeană; bg. peperuda (peperuga) „insectă cu aripi mari și pestrițe”; pepeluga „cenușăreasă”; pirpirună „fluture”, „mac”; babarugă, băbărugă, băbăruță, falsă etimologie populară (Mihăescu 2005: 90-91).

14 Vezi și alte denumiri alocate acestui obicei la Vulcănescu 1985: 418.

15 Vezi și alte semnificații la Vulcănescu 1985: 419; vezi alte detalii la Cuceu I.; Cuceu M. 1988: 78-84; Pop 2011: 167-183; Kernbach 2004: 478-479.

16 Un studiu interesant, realizat din perspectivă lingvistică şi pragmatică, a fost elaborat de Munteanu-Siserman, M. 2015: 131-150.

17 Vezi un studiu complex despre brand la Felecan, D. 2015: 17-24. („Din punct de vedere cultural și socioeconomic, este interesant de urmărit impactul pe care NB românești actuale îl au în rândul consumatorilor români și străini, în ce măsură le determină alegerile și în ce fel reușesc să-i transforme din potențiali cumpărători în consumatori fideli ai produsului respectiv"; 2015: 23). 
dacă pornim de la premisa că produsul este conceput „pentru ocazii speciale («ziua numelui»)" (Munteanu-Siserman 2015: 140), respectiv cu ocazia sărbătorii respective.

\section{Concluzii}

Sărbătorile și obiceiurile analizate în acest articol au un impact deosebit asupra oamenilor din lumea satului românesc. Aceste manifestări folclorice au atras atenția unor specialiști avizați - Antoaneta Olteanu ${ }^{18}$, Ion Ghinoiu ${ }^{19}$ etc. Binaritatea sacruprofan, perspectiva interdisciplinară (lingvistică, etnologică, religioasă, mitologică), izotopiile (avimorfă, umană, supraumană, zoomorfă), eponimia, analiza sincronică, toponimia, pornind de la hidronime, oiconime, microtoponime, hodonime, subliniază complexitatea temei.

\section{Bibliografie}

*** Biblia. 1997. Tipărită sub îndrumarea și cu purtarea de grijă a Prea Fericitului Părinte Teoctist, Patriarhul Bisericii Ortodoxe Române, cu aprobarea Sfântului Sinod, București: Institutul Biblic și de Misiune al Bisericii Ortodoxe Române.

***Dicționarul explicativ al limbii române. 1998. Ediția a II-a. București: Univers Enciclopedic, Academia Română, Institutul de Lingvistică „Iorgu Iordan”.

***Sărbători și obiceiuri. Răspunsuri la chestionarele Atlasului Etnografic Român. 2004. Coordonator: Ion Ghinoiu, vol. IV, Moldova, București: Enciclopedica, Academia Română, Institutul de Etnografie și Folclor „C. Brăiloiu”, Corpus de documente etnografice.

***Sărbători și obiceiuri. Răspunsuri la chestionarele Atlasului Etnografic Român. 2003. Coordonator: Ion Ghinoiu, vol. III, Transilvania, București: Enciclopedica, Academia Română, Institutul de Etnografie și Folclor „C. Brăiloiu”, Corpus de documente etnografice.

*** Sărbători și obiceiuri. Răspunsuri la chestionarele Atlasului Etnografic Român. 2001. Coordonator: Ion Ghinoiu, vol. I, Oltenia, București: Enciclopedică, Academia Română, Institutul de Etnografie și Folclor „C. Brăiloiu”, Corpus de documente etnografice.

Constantinescu, N. A. 1963. Dicționar onomastic românesc. Bucureşti: Academia Română.

Cuceu, I., M. Cuceu. 1988. Vechi obiceiuri agrare românești. București: Minerva.

Eusebiu de Cezareea. 1987. Istoria Bisericească. Martiri din Palestina, traducere de pr. prof. T. Bodogae. București: Institutul Biblic și de Misiune al Bisericii Ortodoxe Române.

Felecan, D. 2015. Numele de brand: repere de analiză. În Proceedings of the Third International Conference on Onomastics "Name and Naming", Conventional / Unconventional in Onomastics, O. Felecan (ed.), 17-24. Cluj-Napoca: Mega \& Argonaut.

Felecan, N. 2013. Sacru și profan în denumirea mănăstirilor din România. În Proceedings of the Second International Conference on Onomastics "Name and Naming", Onomastics in

18 Vezi detalii despre sfinți/sărbători: Sfântul Alexie (Olteanu 2001: 155-157); Blagoveștenie (Olteanu 2001: 165-168); Sân-Georgiu (Olteanu 2001: 205-209); Sântandrei (Olteanu 2001: 503-506).

19 Vezi detalii despre sfinții, sărbătorile, obiceiurile menționate în acest articol: Alexie (Ghinoiu 2013: 17-18); Buna Vestire (Ghinoiu 2013: 54); Caloian (Ghinoiu 2013: 60-61); Păpălugă/Păpărudă (Ghinoiu 2013: 2019); Sângiorz (Ghinoiu 2013: 244-245); Sântandrei (Ghinoiu 2013: 247). 
Contemporary Public Space, Baia Mare, May 9-11, O. Felecan (ed.), 431-439. Cluj-Napoca: Mega \& Argonaut.

Felecan, N. 2011. Între lingvistică şi filologie. Cluj-Napoca: Mega.

Felecan, O. 2013. Hodonimie românească - între autohtonism şi cosmopolitism. În Proceedings of the Second International Conference on Onomastics "Name and Naming", Onomastics in Contemporary Public Space, O. Felecan (ed.), 318-328. Cluj-Napoca: Mega \& Argonaut.

Ghinoiu, I. 2013. Dicționar. Mitologie română. București: Univers Enciclopedic Gold.

Ghinoiu, I. 2005. Comoara satului. Calendar popular. București: Academia Române.

Graur, Al. 1965. Nume de persoane. București: Editura Științifică.

Kernbach, V. 2004. Dicționar de mitologie generală. București: Albatros.

Marian, S. F. 2011. Sărbătorile la români. Studiu etnografic, vol. II. București: Saeculum I. O.

Mihăescu, D. 2005. Contribuții etimologice și lexicale. Bucureşti: Academia Română.

Munteanu-Siserman, M. 2015. Nume de vinuri și de soiuri de struguri românești. În Nume și simțuri: corespondențe semantice în configurații denominative, 131-150. Cluj-Napoca: Mega \& Argonaut.

Olteanu, A. 2001. Calendarele poporului român. Iași: Paideia.

Pătruț, I. 2005. Studii de onomastică românească. Cluj-Napoca: Clusium.

Petrache, T. 1998. Dicționar enciclopedic al numelor de botez. București: Anastasia.

Pop, D. 2011. Obiceiuri agrare în tradiția populară românească. Cluj-Napoca: Dacia XXI.

Răchișan, D. A., C. T. Morariu 2017. The cuckoo in the mentality of Romanians from the traditional community. În Identity, Nation and Dialogue, Section: History, Political Sciences, International Relations, I. Boldea, C. Sigmirean (eds), 158-166. Tîrgu-Mureș: Arhipelag XX1 Press. http://www.upm.ro/gidni/GIDNI-04/GIDNI\%2004\%20-\%20History.pdf (accesat în septembrie 2017).

Răchișan, D. A., C. T. Morariu. 2016. Sântandrei [Saint Andrew] in the mentality of people from the Romanian traditional community. În Studies on Literature, Discourse and Multicultural Dialogue, History and Cultural Mentalities, I. Boldea (coord.), vol. 4, 24-36. Tîrgu-Mureș: Arhipelag XXI Press. http://www.upm.ro/ldmd (accesat în septembrie 2017).

Vulcănescu, R. 1985. Mitologie română. București: Editura Academiei.

\section{Webografie}

Viața Sf. Cuvios Alexie, omul lui Dumnezeu. https://doxologia.ro/viata-sfant/viata-sfantului-cuvios-alexie-omul-lui-dumnezeu (accesare site: 29 august 2017).

http://wine-boutique.ro/vinuri/vinuri-romanesti/sfantul-andrei (accesare site: 29 august 2017).

http://www.vinmag.ro/oprisor-sfantul-gheorghe-2011.html (accesare site: 29 august 2017). http://vinul.ro/caloian-de-oprisor.html (accesare site: 29 august 2017).

https://ro.wikipedia.org/wiki/List\%C4\%83_de_cursuri_de_ap\%C4\%83_din_ Rom\%C3\%A2nia___A (accesare site: 30 august 2017).

http://strazi.rou.ro/ (accesare site: 01 septembrie 2017).

Ghidul mănăstirilor din România. http://ortodox.ro/manastiri (accesare site: 01 septembrie 2017). 